\title{
Seasonal dynamics of plankton in relation to some environmental factors in a Beel ecosystem
}

\author{
M.M.R.Chowdhury ${ }^{1}$, M.R.K.Mondol ${ }^{2 *}$, and S. Dewan ${ }^{1}$ \\ ${ }^{1}$ Department of Fisheries Management, Bangladesh Agricultural University, Mymensingh-2202, Bangladesh, \\ ${ }^{2}$ Department of Fisheries, University of Rajshahi, Rajshahi-6205, Bangladesh
}

\begin{abstract}
Seasonal dynamics of plankton, water temperature, conductivity, $\mathrm{pH}$, total alkalinity, phosphatephosphorus and nitrate-nitrogen of Burulia beel were measured. These values were within the acceptable ranges. In the present study, water temperature, $\mathrm{pH}$, Nitrate-nitrogen, Phosphate-phosphorus were found to range from 13.50 to $30.50^{\circ} \mathrm{C}, 6.21$ to $7.33,1.36$ to $2.85 \mathrm{mg} / \mathrm{l}$ and 0.07 to $0.71 \mathrm{mg} /$, respectively. The range of total plankton was from $12.67 \times 10^{5}$ to $80.83 \times 10^{5}$ cells/l with mean value $29.71 \pm 19.98 \times 10^{5}$ cells/l. A total of 47 genera of plankton was recorded belonging to Chlorophyceae, Bacillariophyceae, Cyanophyceae, Euglenophyceae, Dinophyceae, Crustacea and Rotifera. Among phytoplanktonic Chlorophyceae was the most dominant group contributing $46 \%$ of the total. Cyanophyceae was the least dominant group. From zooplankton, Crustacea was the most dominant group contributing $71 \%$ of the total zooplankton. The greatest abundance of phytoplankton was recorded in September to November with an average number $70.67 \times 10^{5}$ cells/l and the minimum in April with an average number $38.33 \times 10^{5}$ cells/l. The abundance of zooplankton showed two peaks, one in the months of August-October and another in the months of April-June. Phytoplankton and zooplankton have a direct relationship with each other.
\end{abstract}

Key words: Burulia beel, phytoplankton, zooplankton

\section{Introduction}

Beels are sauser-shaped depression of marshy characters usually formed by changed river system. It represents the transitional phase between the terrestrial and aquatic systems with water table at or near the surface or the land is covered with shallow depth of water. Soil and water of beels are very productive and are inhabited by distinct fauna and flora. They serve as natural habitats, breeding, feeding and spawning ground of large and small indigenous fishes of different food habits (Jha, 1989). People living in village around the beels harvest the fish almost round the year without any investment except catching devices. A large portion of rural families is engaged in part time fishing from the floodplains (Hughes et al., 1994). But Beel fishery is being deteriorating day by day due to aforesaid uncoordinated multiple use of water. Beel fishery should be preserved for augmenting fish production and ecological balance of this habitat. On the other hand, success of aquaculture depends almost completely on the quality of different environmental factors. A thorough knowledge of abundance of plankton and its quality in time and space in relation to environmental condition has become a prerequisite for fish production. So, a one year study programme was carried out to know the composition and abundance of plankton population and monthly changes of some water quality parameters as well as plankton population of Burulia beel.

\section{Materials and Methods}

Location: Burulia Beel located at Gobindaganj Upazila under Gaibandha district. It is a semi-closed waterbody with three inlets and outlets. Of these three inlets, to are connected with two canals and one with floodplain.
These inlets are screened during rainy season to prevent the escape of stocked fish. The basin depth of Burulia Beel ranged from 0.34 -2.74 m (ARDMCS, 2003).

Procedure of study: Phytoplankton and water samples were collected monthly from July, 2003 to June 2004 from six different sites of the Beel. Sampling was carried out between 9.00 and $11.30 \mathrm{am}$. Ten liter water was collected from each site by a plastic bucket and kept on wooden boat. Water temperature, $\mathrm{pH}$ and conductivity were measured directly from the collected water using a digital water proof $\mathrm{pH}$, EC/TDS and temperature meters (HANNA instruments, model: HI 98129- HI 98130, Italy). Then $100 \mathrm{ml}$ sample of previously collected water of each site were taken in a bottle and $\mathrm{NO}_{3}-\mathrm{N}$ were measured directly from reading of spectrophotometer $\mathrm{HACH}$ water analysis Kit (HANNA instrument, model HI 93728, Italy) with one packet of HI 93728 reagent for $10 \mathrm{ml}$ filtered water samples. The concentration of phosphatephosphorus was measured directly from reading of spectrophotometer HACH water analysis Kit (HANNA instrument, model HI 93713, Italy) with one packet of HI 93713 reagent for $10 \mathrm{ml}$ filtered water samples.

For plankton analysis, the collected 10 liter water was filtered through plankton net of $10,30 \mu$ mesh size and finally concentrated to $20 \mathrm{ml}$. The filtrates were then immediately preserved in 5\% buffered formalin for subsequent studies. Microscopic identification upto genera was performed following the standard manual. Each sample was stirred well just before microscopic examination. One $\mathrm{ml}$ of stirred sample was transferred to Sedgewick-Rafter cell (S-R cell) with a wide mouth pipette. Identification and enumeration were done by a compound microscope (NOVA 950 ES). All the plankton present in randomly chosen 20 squares grids of S-R cell was counted. The mean of three counts was then calculated for each plankton component occurring in the 
total count. Finally the quantitative counts of phytoplankton were done according to Rahman (1992) and expressed in cells/L. Qualitative studies were done after Peenak (1953), Ward \& Whipple (1954), Needham \&Needham (1962), Prescott (1964), APHA (1992) and Bellinger (1992).

\section{Results and Discussion}

Environmental parameters: Water temperature was in the range of $13.50-30.50^{\circ} \mathrm{C}$ with a mean $24.45 \pm 5.47^{\circ} \mathrm{C}$. The highest temperature was recorded in the month of June and lowest in December. Ehasan et al. (1996) found highest water temperature $\left(31.7^{\circ} \mathrm{C}\right)$ in the month of June and the lowest $\left(25.2^{\circ} \mathrm{C}\right)$ in January in Chanda Beel. Saha \& Hossain (2002) found the highest water temperature in August $\left(31^{\circ} \mathrm{C}\right)$ and the lowest in January $\left(19.25^{\circ} \mathrm{C}\right)$ in Saldu Beel which was more or less similar to the present study. The water temperature fluctuated due to the seasonal variations of sunshine/rain. Conductivity varied from 33.67-61.83 $\mu \mathrm{S} / \mathrm{cm}$ with mean value $49.51 \pm 9.58 \mu \mathrm{S} / \mathrm{cm}$. The maximum value of conductivity was found in February whereas the minimum in August. This value was more or less similar to the results of Patra \& Azadi (1987) who found conductivity from $51.58-147.65 \mathrm{uS} / \mathrm{cm}$ in Kaptai lake. $\mathrm{pH}$ is called the index of waterbody. In the present study, $\mathrm{pH}$ of water ranged from 6.21-7.33 with a mean of $6.79 \pm 0.35$. The highest $\mathrm{pH}$ value 7.33 was recorded in July and the lowest 6.21 in April. The present finding agree with the findings of Patra \& Azadi (1987) who recorded the range of $\mathrm{pH}$ values from 6.89-8.15 in Halda river and Khan et al. (1990) from 6.96-8.40 in Bachhra reservoir. Acharjee et al. (1997) also found $\mathrm{pH}$ from 6.27.1 in Dighali Beel which was similar to the present study. The fluctuation might be due to rise in temperature and decrease in water level for evaporation, rainfall, supply of slaked lined, soil properties etc. Total alkalinity of water was recorded from 20.83-58.80 (mg/l) with mean value $35.79 \pm 10.62 \mathrm{mg} / \mathrm{l}$. The highest total alkalinity was recorded in the month of April and the lowest in September. Bhuiyan (1970) recorded the total alkalinity of medium productive water body ranging from 25-100 mg/l. Chowdhury \& Mazumder (1981) reported more or less static alkalinity in Kaptai Lake (40 mg/l).

Nutrient content: Nitrate-nitrogen $\left(\mathrm{NO}_{3}-\mathrm{N}\right)$ concentration ranged $1.36-2.85 \mathrm{mg} / \mathrm{l}$ with a mean $2.17 \pm 0.47 \mathrm{mg} / \mathrm{l}$. The maximum $\mathrm{NO}_{3}-\mathrm{N}$ was recorded in the month of October and minimum in the month of April. Islam and Saha (1975) recorded $\mathrm{NO}_{3}-\mathrm{N}$ from 0.25-6.00 ppm in Ramna Lake and Mazumder et al. (1997) from 0.90-6.25 ppm in different water bodies in West Bengal (India). Jewel (2001) recorded $\mathrm{NO}_{3}-\mathrm{N}$ values ranging from $0.80 \mathrm{ppm}$ in July and $2.90 \mathrm{ppm}$ in September at the mouth of Maheshkhali channel, Bay of Bengal, Cox's Bazar. In the present study, concentration of Phosphate-phosphorus (mg/l) was in $0.07-0.71 \mathrm{mg} / \mathrm{l}$ with a mean $0.32 \pm 0.18 \mathrm{mg} / \mathrm{l}$. The maximum $\mathrm{PO}_{4}-\mathrm{P}$ was recorded in the month of May and minimum in the month of September. The findings of present study were more or less in conformity with the findings of Islam \& Saha (1975). The range of $\mathrm{PO}_{4}-\mathrm{P}$ values recorded by them was 0.02-2.80 ppm, in Ramna Lake. Chowdhury \& Mazumder (1981) reported $\mathrm{PO}_{4}-\mathrm{P}$ 0.27-0.83 ppm in Kaptai Lake. Jewel (2001) found the wide range of $\mathrm{PO}_{4}-\mathrm{P}$ 0.06$3.20 \mathrm{ppm}$ at the mouth of the Maheshkhali channel, Cox's Bazar. The varied concentration of $\mathrm{PO}_{4}-\mathrm{P}$ in the present investigation might be due to soil properties, decomposition of aquatic materials and utilization by algae, absence of inflow in summer, rainfall, etc.

Plankton Population: Plankton populations in the studied Beel was represented by 47 genera. Phytoplankton 35 genera of which 17 from Chlorophyceae (17) followed by 9 Cyanophyceae, 6 Bacillariophyceae, 2 Euglenophyceae and 1 Dinophyceae. The zooplankton population was composed of 12 genera belonging to two major groups: Crustacea and Rotifera- each was represented by 6 genera. Ehshan et al. (2000) observed 44 genera of phytoplankton in Chanda Beel. Saha \& Hossain (2002) identified 46 genera of phytoplankton and 27 genera of zooplankton in Saldu Beel. Masud et al. (1996) reported 11 genera of zooplankton belonging to 9 families in derelict, extensive and semi-intensive fishpond. Similarly Dewan et al. (1991) identified 9 genera of zooplankton belonging to 1 Hydrozoan, 5 Crustacea and 3 Rotifera. Razzaque et al. (1995) found 87 genera of phytoplankton and 29 genera of zooplankton in Halti Beel. In the present study, ranges of total plankton recorded were $12.67 \times 10^{5}-80.83 \times 10^{5}$ cells $/ \mathrm{l}$ with mean abundance of $29.71 \pm 19.98 \times 10^{5}$ cells/l. Patra \& Azadi (1987) recorded more or less equal number of total plankton in Halda river. Khan et al. (1990) also measured total abundance of plankton between 70 unit/l and 47.62 unit/l in Bachhra reservoir. The maximum abundance of total plankton was recorded in the month of October and minimum values were recorded in the month of January.

Phytoplankton population: The total abundance of phytoplankton ranged between $83.3 \times 10^{4}-70.67 \times 10^{5}$ cells $/ \mathrm{l}$ with a mean of $22.78 \pm 18.34 \times 10^{5}$ cells/l. Razzaque et al. (1995) published a figure of $11.70 \pm 4.60 \times 10^{3}$ $47.70 \pm 34.60 \times 10^{3}$ cells/l in Halti Beel. The combined data of one year showed peak of phytoplankton in October. Similarly Singh (1960) reported primary peak of phytoplankton in the month of September-October in Uttar Pradesh in India. Razzaque et al. (1995) observed similar dynamics in Halti Beel. In Chanda Beel, maximum abundance of phytoplankton was observed in October (Ehshan et al., 2000). In the present investigation the lowest abundance of phytoplankton was obtained in the month of April. Similar result was obtained in Halti Beel and Chanda Beel (Razzaque et al., 1995 and Ehshan et al., 2000). The results of seasonal variation in environmental parameters and plankton population suggest that the favourable period for primary production in Burulia Beel is October to November when nutrients accumulated from freshwater run-off due to monsoon rainfall in these months (Fig. 1 and 2). On the other hand, phytoplankton abundance and taxonomic diversity depend upon the supply of nutrients in natural waters. In the present study, the highest cell density and diversity in phytoplankton genera was found in October, when $\mathrm{NO}_{3}-\mathrm{N}$ concentration 
(2.85 mg/l) was found high and $\mathrm{PO}_{4}-\mathrm{P}$ concentration (0.13 ppm) was lowe (Fig. 3). So, it can be assumed that high temperature and $\mathrm{NO}_{3}-\mathrm{N}$ concentration may be important factors for maximum cell density and taxonomic diversity of phytoplankton in Burulia Beel.

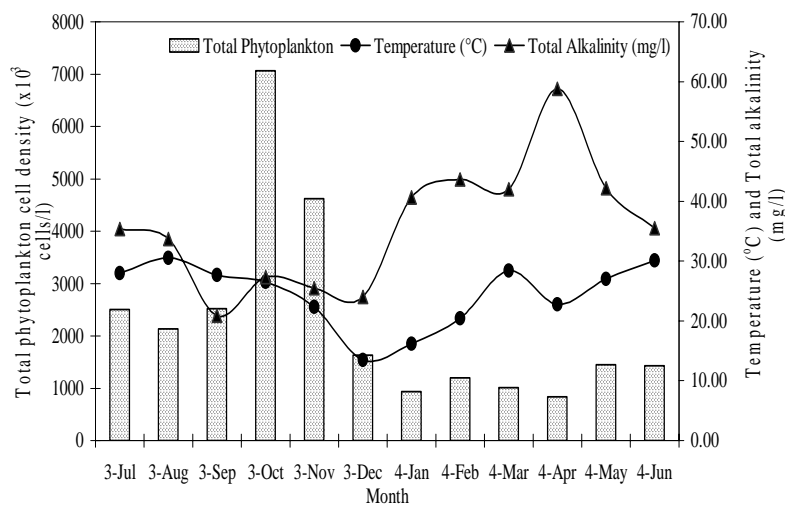

Fig. 1. Effects of temperatures $\left({ }^{\circ} \mathrm{C}\right)$ and total alkalinity (mg/l) on the seasonal abundance of phytoplankton population in Burulia beel during the study period.

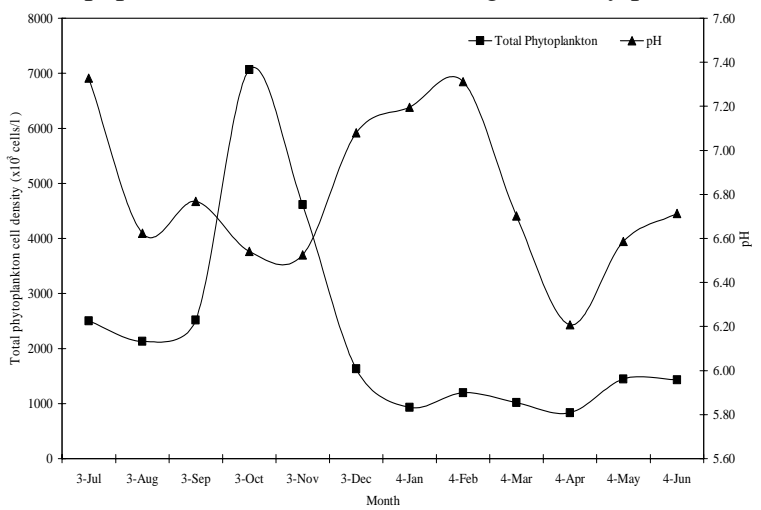

Fig. 2. Effects of $\mathrm{pH}$ on the seasonal abundance of phytoplankton population in Burulia beel during the study period

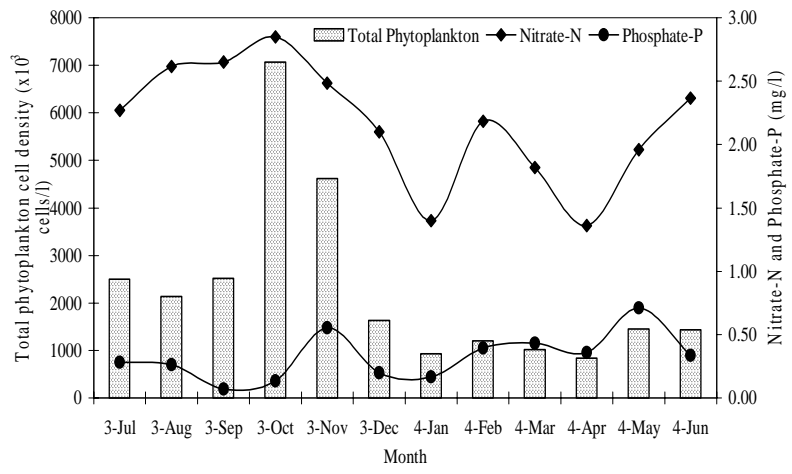

Fig.3. Effects of Nitrate- $\mathrm{N}$ and Phosphate-P concentrations (mg/l) on the seasonal abundance of total phytoplankton population in Burulia beel during the study period.

In Burulia Beel, Chlorophyceae was dominant phytoplankton and Cyanophyceae was least dominant. Khan et al. (1990) obtained similar results in Bachhra reservoir. In Kaptai lake, Ahmed et al. (1992) obtained
77.5\% Chlorophyceae and 1.1\% Dinophyceae. Yousuf \&Parveen (1990) and Saha \& Hossain (2002) observed almost similar phenomenon in Dal lake and Saldu Beel, respectively.

Zooplankton population: The population dynamics of zooplankton ranged $33.3 \times 10^{4}-11.50 \times 10^{5}$ cells/ 1 with a mean value of $96.3 \pm 28.6 \times 10^{4}$ cells/l. The value is more or less close to those reported by Patra \& Azadi (1987) in Halda river, Razzaque et al. (1995) in Halti Beel and Ehshan et al. (2000) in Chanda Beel. In the present study, Crustacea was the most dominant group in Burulia Beel (73\%). Similarly Khan et al. (1990) and Masud et al. (1996) observed Crustacea dominant zooplankton in fish ponds. On the other hand, Ahmed et al. (1992) and Razzaque et al. (1995) reported Rotifera dominant zooplankton in Kaptai Lake and Halti Beel, respectively. Total zooplankton populations showed two peaks, one in September and another in April made by Das and Srivastava (1956) in a pond. Similar bimodal peak of zooplankton was reported by Razzaque et al. (1995).

In the present investigation, both phytoplankton and zooplankton showed direct relationship as those obtained by Patra \& Azadi (1987) in Halda river; Ali et al. (1985) in a pond and Razzaque et al. (1995) in Halti Beel (Fig. 4). However, Das \& Srivastava (1956) observed inverse correlation between phytoplankton and zooplankton. During the study period zooplankton growth cycle was noticeably less than the phytoplankton abundance almost throughout the study period. Patra \& Azadi (1987) observed similar phenomenon in Halda river.

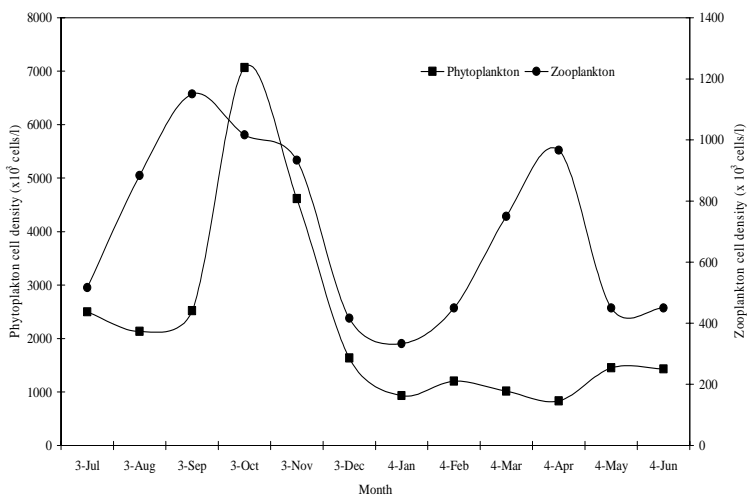

Fig.4: Temporal variation of phytoplankton and zooplankton in Burulia Beel during the study period.

\section{Acknowledgments}

The author is immensely grateful to Aquatic Research Development Management and Conservation Study (ARDMCS) funded by World Bank for its financial and technical supports in performance of this research work. The Authors are indebted to Professor Dr. Somen Dewan, Department of Fisheries Management and Professor Dr. Rezaul Hassan, Department of Aquaculture, Bangladesh Agricultural University, Mymensingh for his co-operation and advice during the study period. 


\section{References}

Acharjee, B., Dutta, A. \& Chowdhury, M. 1997. An account of the aquatic macrophytes in some beels of lower Brahmaputra basin, Assam. In: Changing perspectives of Inland Fisheries (eds. Vass, K.K. and Sinha, M.). Proc. Nat. Seminar, March 16-17, 1997 IFSI, Barrackpore, India, 228-234 pp.

Ahmed, K.K., Halder, G.C. \& Saha, S.B. 1992. Limnological studies on Kaptai lake. Final Report. Fisheries Research Institute, Kiverine sub-station, Rangamati, 36 pp.

Ali, M.M., Islam, M.A. \& Habib, M.A.B. 1985. Monthly abundance of zooplankton and correlation of various dominant species and nauplius of zooplankton with some water characters in a pond. Univ. J. Zool. Rajshahi Univ. 4: 42-49.

APHA. 1992. Standard methods for the examinations of water and waste water. American Public Health Association, 1015 Eighteenth Street, New York, Washington D. C., 20035, 874 pp.

ARDMCS. 2003. Baseline information of five beels/floodplains/rivers under aquatic biodiversity assessment study. ARDMCS, Fourth Fisheries Project (FFP), DoF, GoB/GEF/Worldbank, Dhaka, Bangladesh, 30 pp.

Bellinger, E.G. 1992. A key to common algae: Freshwater, estuarine and some coastal species. The Institute of Water and Environment Management, London, UK.

Bhuiyan, B.R. 1970. Physico-chemical qualities of some ancient tanks of Sibsagar, Asam. Enviro. Health, 12:129-134.

Chowdhury, S.H. \& Mazumder, A. 1981. Limnology of Lake Kaptai: Physico-chemical Features. Bangladesh $J$. Zool., 9(1): 59-72.

Das, S.A. \& Srivestava, V.K. 1956. Quantitative on freshwater plankton of a fish tank in Lucknow, India. Proc. Nat. Acad. Soc. India, 26: 85-91.

Dewan, S., Wahab, M.A., Beveridge, M.C.M., Rahman, M.H. \& Sarker, B.K. 1991. Food selection, electivity and dietary overlap among planktivorous Chinese and Indian Major Carps and fingerlings grown in extensively managed, rain-fed ponds in Bangladesh $J$. Aquacult. \& Fish. Manag. 22:277-294.

Ehshan, M.A., Hossain, M.S. Razzaque, A. \& Alam, M.S. 2000. Kua-an unusual but important fishery of Chanda beel. Bangladesh J. Zool. 28(1): 69-74.

Ehshan, M.A., Hossain, M.S., Mazid, M.A., Mollah, M.F.A., Rahman, S. \& Rezzaque, A. 1996. Limnology of Chanda beel. Bangladesh J. Fish Res. 1(1): 31-34.

Hughes, R., Adnan, S. \& Dalal-Clayton, B. 1994. Floodplains on flood plans. International Institute for Environment and Development, and Research and Advisory Services, London.

Islam, A.K.M.N. \& Saha, J.K. 1975. Limnological studies of the Ramna lake at Dacca. Dacca Uni. Studies, 23(2): 39-46.

Jewel, A.S. 2001. Seasonal dynamics of phytoplanktons in relation to some environmental parameters at the mouth of the Maheshkhali Chaneel Cox's Bazar,
Bangladesh. M.S. thesis, Department of Fisheries Management, Faculty of Fisheries, Bangladesh Agricultural University, Mymensingh, 90 pp.

Jha, B.C. 1989. Classification, Management and Status of fish production in beels. Inland Fisheries Society of India. CIFRI, Barrackpore, India, 52-60 pp.

Khan, M.A., Srivastava, K.P., Dwivedi, R.K., Singh, D.N., Tyagi, R.K. \&Mehrotra, S.N. 1990. Significance of ecological parameters in fisheries management of a newly impounder reservoir-bachhra reservorir. In: Contributing to the fisheries of Inland open water system in India, Jhingran, A.G., Unnithun, V.K. \& Ghosh, A.). (eds). Part-I, Inland Fisheries Society of India. CIFRI, Barrackpore, India, 100-108 pp.

Masud, A.K.M.S., Chowdhury, H.A., Rahmatullah, S.M., Islam, M.A. \& Islam, A.K.M.S. 1996. Comparative study on the zooplankton population of Derelict, Extensive and semi-intensive Fish ponds. Bangladesh $J$. Aquaculture, 18:33-37.

Mazumder, S., Sengupta, A., Pati, K., Sengupta, K.K. \& Santra, S.C. 1997. Water quality, plankton and periphyton assessment in different water bodies in West Bengal (India). In: Changing perspectives of Inland Fisheries (eds. Vass, K.K. and Sinha, M.). Proceedings of the National Seminar, March 16-17, 1997, IFSI, Barrackpore, India, 187-190 pp.

Needham, J.G. \& Needham. P.R. 1962. A guide to the study of freshwater biology. $5^{\text {th }}$ edn. Liolden-day, Inc., San Francisco, 106 pp.

Patra, R.W.R. \& Azadi, M.A. 1987. Ecological studies on the planktonic organisms of the Halda River. Bangladesh $J$. Zool. 15(2): 109-123.

Peenak, R.W. 1953. Freshwater invertebrate of the United States. Ronald Press, New York, 679 pp.

Presscott, G.W. 1964. Algae of the western Great lakes area. Wm. C. Brown. Co., Inc. Dubyque. Iowa., 946 pp.

Rahman, M.S. 1992. Water quality management in aquaculture. BRAC prokashana, Dhaka, pp 83-84.

Razzaque, A., Hossain, M.S., Islam, A.K.M.S., Hossain, M.M.M. \& Ehshan, M.A. 1995. Study on plankton population of Halti beel at Natore, Bangladesh. Bangladesh J. Aquaculture, 17: 19-23.

Saha, B.K. \& Hossain, M.A. 2002. Saldu beel fishery of Tangail. Bangladesh J. Zool. 30(20): 187-194.

Singh, V.P. 1960. Phytoplankton ecology of the inland waters of Utter Pradesh. Proc. Symp. Algal. ICAR, New Delhi, pp. 243-271.

Ward, H.B. \& Whipple, G.C. 1954. Freshwater Biology. John Willey and Sons Inc., New York, 128 pp.

Yousuf, A.R. \&Parveen, M. 1990. Phytoplankton dynamics in Dal lake, Kashmir. In: Contributing to the fisheries of Inland open water system in India. (eds. Jhingran, A.G., Unnithun, V.K. and Ghosh, A.). Part-I. Inland Fisheries Society of India. CIFRI; Barrackpore, India, 58-67 pp.

Manuscript received on 23.05.2008, accepted on16.08.2008 